Relations industrielles

Industrial Relations

\title{
Unions, Wages and Total Compensation in Canada
}

An Empirical Study

Syndicats, salaires et rémunération globale au Canada

Une analyse empirique

\section{Sindicatos, salarios y compensación total en Canadá \\ Un estudio empírico}

\section{Stéphane Renaud}

Volume 53, numéro 4, automne 1998

URI : https://id.erudit.org/iderudit/005297ar

DOI : https://doi.org/10.7202/005297ar

Aller au sommaire du numéro

Éditeur(s)

Département des relations industrielles de l'Université Laval

ISSN

0034-379X (imprimé)

1703-8138 (numérique)

Découvrir la revue

\section{Citer cet article}

Renaud, S. (1998). Unions, Wages and Total Compensation in Canada: An

Empirical Study. Relations industrielles / Industrial Relations, 53(4), 710-729.

https://doi.org/10.7202/005297ar

Tous droits réservés (C) Département des relations industrielles de l'Université Laval, 1998
Ce document est protégé par la loi sur le droit d'auteur. L'utilisation des services d'Érudit (y compris la reproduction) est assujettie à sa politique d'utilisation que vous pouvez consulter en ligne.

https://apropos.erudit.org/fr/usagers/politique-dutilisation/ 


\section{Unions, Wages and Total Compensation in Canada}

\section{An Empirical Study ${ }^{1}$}

\section{STÉPHANE RENAUD}

École de relations industrielles, Université de Montréal, Montréal.

This study presents the first empirical evidence of the impact of unions on benefits and total compensation in Canada. It also provides new evidence on the union wage impact and union wage differentials for a wide range of selected groups in the labour market. Using micro data from the Canadian General Social Survey (GSS) of 1989, the results show that the union impact is to increase total compensation by 12.4 percent, compared to an impact of 10.4 percent on wages. Even though the union impact on total compensation is 2 percent greater than the impact on wages, given that benefits comprise only about 6 percent of total compensation in this sample, the percentage impact of unions on benefits is estimated to be 45.5 percent. This latter estimate implies a very substantial impact of unions on benefits in Canada, as large or larger than those reported in the United States.

The body of Canadian literature is robust in demonstrating empirically that unions provide their members with a rather large wage premium. Studies using aggregate data tend to show a positive wage differential of about 10 to 20 percent (Kumar and Stengos 1985; MacDonald 1983; MacDonald and Evans 1981; Kumar 1972), and studies using micro data report a wage premium that lies in the range of 10 to 25 percent (White 1994; Swidinsky and Kupfeschmidt 1991; Kumar and Stengos 1986; Robinson and Tomes 1984; Simpson 1985; Grant, Swidinsky and Vanderkamp 1987). This union differen-

1. The author thanks Professor Morley Gunderson, the students at the Ph.D. Research Seminar of the Centre for Industrial Relations (University of Toronto) and the two anonymous reviewers for their helpful comments. The Fonds pour la Formation de Chercheurs et l'Aide à la Recherche provided financial support for the research. 
tial has fluctuated over the years. It was approximately 15 percent at the beginning of the 1970s, increased in the mid-1970s, peaking around 25 percent at the end of that decade, and declined during the 1980s (Renaud 1997). The Canadian estimates of the union-nonunion wage differentials are now quite dated and no recent estimates are available.

The Canadian literature has concentrated almost exclusively on the union impact on the hourly wage rate, omitting other important components of compensation such as benefits. No studies were found that considered union-nonunion total compensation differentials. Arguably, this is a serious omission since there are theoretical reasons to suggest that unions would have a disproportionately large impact on fringe benefits compared to wages. Union preferences are likely to be shaped by the median union voter who is likely to be older and to prefer fringe benefits like pension, health, and disability benefits. For instance, Swidinsky and Kupferschmidt (1991) show that Canadian unionized workers are between 22 and 25 percent more likely to be covered by a pension plan than their nonunionized counterparts. Union members are also likely to be better paid and hence to buy more fringe benefits with the higher income, especially if there are tax advantages. Unions may be able to monitor and inform their members about those complex benefits. Empirical evidence reported in Freeman and Medoff (1984) for the U.S. confirms that unions have a larger impact on benefits (20-30 percent) than on wages (10-20 percent), which strengthens the idea that studies which focus only on the impact of unions on wages may understate their impact on total compensation.

This study contributes to the empirical literature on the impacts of unions in Canada in two main ways: (1) it provides evidence on unions' impact on fringe benefits and thus on total compensation; and (2) by presenting recent evidence it sheds light on the issue of whether the differential has declined in recent years. The latter question is important given the increased economic interdependence of Canada and the United States and the decline of unionization in the U.S. compared with Canada. The empirical model employed also deals with potential selection bias and reverse causality.

\section{ESTIMATION STRATEGY}

The empirical model specified here deals with the selection bias that can occur if unionized workers sort themselves or are sorted into the union sector on the basis of unobserved factors that can influence wages. Positive selection, for example, can occur if employers are able to select

from the queue of applicants for the high-wage union jobs. Negative selection can occur if less motivated workers seek the protection and security of union jobs. As well, the analysis deals with the potential reverse causal- 
ity that can occur if high wages lead to unionization, for example, because workers in high-wage jobs are likely to want unions as an institutional form of "voice" given that they are unlikely to "exit" from such jobs. To account for the potential selection bias and the simultaneity, the following empirical model is utilized:

$$
\begin{aligned}
& U i=\alpha 0+\alpha 1 Z+\alpha 2 J+\alpha 3(\ln \hat{W} u-\ln \hat{W} n)+\varepsilon u i \\
& \ln W u i=\beta 0+\beta 1 Z+\beta 2 J+\beta 3 I+\beta 4 \lambda+\varepsilon \ln W u i \\
& \ln W n i=\gamma 0+\gamma 1 Z+\gamma 2 J+\gamma 3 I+\gamma 4 \lambda+\varepsilon \ln W n i
\end{aligned}
$$

where union wage $\left(\operatorname{lnW}_{\mathrm{u}}\right)$ and nonunion wage $\left(\operatorname{lnW}_{\mathrm{n}}\right)$, expressed in their natural logarithm, and union membership (U) are determined simultaneously. They are all a function of workers' human-capital characteristics (Z), and characteristics of the industry and the workplace (J). Furthermore, union membership is also a function of each worker's expected union-nonunion wage differential $(\ln \hat{W} u-\ln \hat{W} n)$. This wage differential is more pertinent than the current wage term, since workers are more likely to consider what they would be earning in the other sector when considering whether or not to become a union member. A vector of non-labour-market sources of income (I) is incorporated in equations (2) and (3) since this study, as discussed in the following section, uses data that reports only a measure of annual income from all sources (work, interest, etc.). This vector is included in the wage equations to obtain a better approximation of the wage. The subscript $i$ indicates the individual worker $i$, epsilon $(\epsilon)$ is the error term of each equation, and the lambdas $(\lambda)$ represent the selectivity variables (Inverse Mills Ratio) that will be derived from the union membership equation following Lee's (1978) technique. These selectivity variables are introduced in the wage equations in order to correct for the possible selectivity problem that occurs from the nonrandomness of union membership status.

Unions are expected to have an impact on wages. The magnitude of this impact is unknown, and it is one of the main purposes of this paper to estimate it using measures of wage and total compensation. Derived from equations (2) and (3), the union-nonunion differential is given as:

$\mathrm{e}^{\mathrm{D}}-1$

where $\mathrm{e}=$ inverse natural logarithm and

$$
D=(\beta 0-\lambda 0)+(\beta 1 \bar{Z}-\gamma 1 \bar{Z})+(\beta 2 \bar{J}-\lambda 2 \bar{J})+(\beta 3 \bar{I}-\lambda 3 \bar{I})
$$


and $\bar{Z}, \bar{J}, \bar{I}$ are the full-sample means of respectively : the human capital characteristics vector, the occupational and industrial characteristics vector, and the non-labour-market sources of income vector.

The range of control variables used in the Canadian union wage impact studies, along with their actual impact are summarized in Table 1 for the individual and human-capital variables and for the industry and workplace variables. This table shows that the results linking individual and human-capital characteristics (Z), and characteristics of the industry and the workplace (J), to wage are usually stable and similar from study to study.

The potential for selection bias and reverse causality are dealt with here by the Heckman-Lee technique: (1) first estimate a reduced-form probit of union status in equation (1), in which equations (2) and (3) are substituted; (2) calculate, from the previous reduced-form probit of the union membership equation, selectivity correction variables $(\lambda)$ for every worker i assessed by the Inverse Mills Ratio (that is, the standard normal density function divided by the cumulative distribution of the standard normal [Hirsh and Addison 1986: 126]); and (3) incorporate them into the wage equations (2) and (3). These equations can then be estimated using a simple ordinary-least-squares procedure from which an unbiased expected union-nonunion differential value for every worker $\mathrm{i}$ is obtained.

In estimating equations (1) to (3), one faces an identification problem. Put simply, if the same exogenous variables are used in the union membership and the wage equations, the fitted wage values are then a linear combination of the other variables in the union membership equation (1), and the regression cannot be performed since it violates the assumption of independence of all independent variables (Maddala 1983). The identification problem, however, can be dealt with by excluding at least one variable from each of the equations, or relying on the nonlinearity of the selectivity variables. This paper adopts both strategies in that it relies on the non-linearity of the selectivity variables and it excludes the non-labour-market sources of income variables from the union membership equation (1). These variables appear to be prime candidates for exclusion because they are directly related to the compensation measures, and there is no obvious reason to believe they would be related to a worker's union status.

However, in the literature it is also a common procedure to estimate equations 2 and 3 by applying OLS without correcting for the possible selectivity bias and the reverse causality problem. Authors like Lewis (1986) simply do not trust the results produced by the Heckman-Lee statistical technique. For this reason, this paper will employ the two alternative techniques (OLS and selectivity). A simple application of OLS might produce an upwardly 
TABLE 1 Effect of Individual, Human-Capital, Industry and Workplace
Variables on Wages in Canadian Union Impact Studies

\begin{tabular}{|c|c|c|}
\hline Variables & $\begin{array}{l}\text { Nature of the } \\
\text { Relationship }\end{array}$ & Selected Studies \\
\hline \multicolumn{3}{|c|}{ Individual and Human Capital Variables } \\
\hline \multirow[t]{2}{*}{ Age } & Quadratic: Inverted U & Grant et al. 87; Green 91; Lemieux 93; White 94. \\
\hline & Positive \& Linear & $\begin{array}{l}\text { Kumar \& Stengos (86); Swidinsky \& Kupferschmidt } \\
\text { 91; Christofides \& Swidinsky } 94 .\end{array}$ \\
\hline Sex & $\begin{array}{l}\text { Male Workers = 1: } \\
\text { Positive \& Linear }\end{array}$ & $\begin{array}{l}\text { Christofides \& Swidinsky 94; Grant et al. 87; Kumar \& } \\
\text { Stengos 86; Lemieux 93; Robinson \& Tomes 84; } \\
\text { Simpson 85; Swidinsky \& Kupferschmidt 91; White } 94 .\end{array}$ \\
\hline Education & Positive \& Linear & $\begin{array}{l}\text { Christofides \& Swidinsky 94; Green 91; Kumar \& } \\
\text { Stengos 86; Lemieux 93; Swidinsky \& Kupferschmidt } \\
\text { 91; White 94. }\end{array}$ \\
\hline \multirow[t]{2}{*}{ Tenure } & Quadratic: Inverted U & $\begin{array}{l}\text { Green } 91 \text {; Kumar \& Stengos } 86 ; \text { Swidinsky \& } \\
\text { Kupferschmidt } 91 ; \text { White } 94 .\end{array}$ \\
\hline & Positive \& Linear & Christofides \& Swidinsky 94; Robinson \& Tomes 84. \\
\hline $\begin{array}{l}\text { Work } \\
\text { Experience }\end{array}$ & Quadratic: Inverted U & Robinson \& Tomes 84. \\
\hline Skill Level & Positive \& Linear & $\begin{array}{l}\text { Kumar \& Stengos 86; Robinson \& Tomes 84; Simpson } \\
85 .\end{array}$ \\
\hline Full-Time & $\begin{array}{l}\text { Full-Time Workers = 1: } \\
\text { Positive \& Linear }\end{array}$ & $\begin{array}{l}\text { Green 91; Kumar \& Stengos 86; Lemieux 93; Swidinsky } \\
\& \text { Kupferschmidt } 91 \text {. }\end{array}$ \\
\hline Marital Status & $\begin{array}{l}\text { Married Workers = } 1 \text { : } \\
\text { Positive \& Linear }\end{array}$ & $\begin{array}{l}\text { Christofides \& Swidinsky 94; Grant et al. 87; Kumar \& } \\
\text { Stengos 86; Lemieux 93; Swidinsky \& Kupferschmidt } \\
\text { 91; White 94. }\end{array}$ \\
\hline Language & Mixed Results & Lemieux 93; Robinson \& Tomes 84; White 94. \\
\hline Race & $\begin{array}{l}\text { White Workers }=1 \text { : } \\
\text { Positive \& Linear }\end{array}$ & Lemieux 93; White 94. \\
\hline Immigrant & $\begin{array}{l}\text { Immigrant Workers }=1 \\
\text { Mixed Results }\end{array}$ & : Christofides \& Swidinsky 94; White 94. \\
\hline $\begin{array}{l}\text { Physically } \\
\text { Challenged }\end{array}$ & $\begin{array}{l}\text { Disabled Workers }=1 \text { : } \\
\text { Mixed Results }\end{array}$ & Christofides \& Swidinsky 94; White 94. \\
\hline $\begin{array}{l}\text { Selectivity } \\
\text { Correction }\end{array}$ & Mixed Results & $\begin{array}{l}\text { Grant et al. 87; Green 91; Kumar \& Stengos 86; } \\
\text { Robinson \& Tomes 84; Simpson 85; White } 94 \text {. }\end{array}$ \\
\hline \multicolumn{3}{|c|}{ Industry and Workplace Variables } \\
\hline Size of the Firm & Positive \& Linear & $\begin{array}{l}\text { Christofides \& Swidinsky 94; Swidinsky \& } \\
\text { Kupferschmidt 91; White 94. }\end{array}$ \\
\hline Occupation & $\begin{array}{l}\text { Inter-Occupational } \\
\text { Differences }\end{array}$ & $\begin{array}{l}\text { Christofides \& Swidinsky 94; Grant et al. 87; Green 91; } \\
\text { Lemieux 93; Swidinsky \& Kupferschmidt 91; White 94. }\end{array}$ \\
\hline White Collar & \multicolumn{2}{|c|}{$\begin{array}{l}\text { White Collar Workers = Green } 91 . \\
\text { 1: Mixed Results }\end{array}$} \\
\hline Industry & $\begin{array}{l}\text { Inter-Industrial } \\
\text { Differences }\end{array}$ & $\begin{array}{l}\text { Christofides \& Swidinsky 94; Green 91; Lemieux 93; } \\
\text { Swidinsky \& Kupferschmidt } 91 .\end{array}$ \\
\hline Public Sector & \multicolumn{2}{|c|}{ 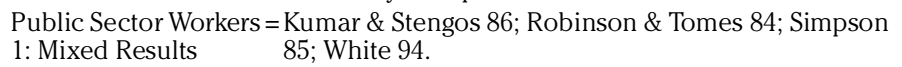 } \\
\hline Manufacturing & \multicolumn{2}{|c|}{$\begin{array}{l}\text { Manufacturing Workers Kumar \& Stengos } 86 . \\
=1 \text { : Mixed Results }\end{array}$} \\
\hline $\begin{array}{l}\text { Geographical } \\
\text { Location of the } \\
\text { Firm }\end{array}$ & Regional Differences & $\begin{array}{l}\text { Christofides \& Swidinsky 94; Grant et al. 87; Green 91; } \\
\text { Lemieux 93; Robinson \& Tomes 84; Simpson 85; } \\
\text { Swidinsky \& Kupferschmidt 91; White } 94 .\end{array}$ \\
\hline Union Density & Positive \& Linear & $\begin{array}{l}\text { Grant et al. 87; Kumar \& Stengos 86; Robinson } \\
\text { \& Tomes } 84 .\end{array}$ \\
\hline
\end{tabular}


biased differential if the reverse causality problem is true; and it will also upwardly bias the differential coefficient if the selectivity problem is real.

\section{DATA AND VARIABLES}

The empirical analysis presented in this paper is based mainly on crosssectional data from the 1989 Canadian General Social Survey: Education and Work (GSS). ${ }^{1}$ The initial sample included 11,728 Canadian households from which one respondent was randomly selected. A total of 9,338 respondents answered the questionnaire in the official language of their choice, resulting in a response rate of 80 percent, which is very high for such a survey. Of the 9,338 respondents, 3,661 were eliminated from this study because they were either out of the labour market or unemployed during the reference week. Of the remaining 5,677 individuals, an additional 1,593 respondents were eliminated because they were either self-employed, managers or administrators. This further restriction was required in order to increase the comparability of the union and nonunion samples since in Canada these three groups are not usually permitted to unionize, and no comparable group would have been found in the union sector. This restriction reduced the working sample to 4,084 respondents.

Other restrictions were also necessary to reduce possible wage measurement errors. The hourly wage rate was derived using annual income because this survey only reports annual income and number of hours worked per week. To minimize bias from this procedure, the analysis was restricted to fulltime workers who were employed year-round, and who held only one job. These restrictions are especially important in order to minimize possible risks of contamination of the compensation measure by other non-labour-market sources of income. These additional restrictions trimmed the working sample to 2,333 individuals. Of these 2,333 respondents, 11 were eliminated because they did not report their union status and 313 were omitted because they did not indicate their annual income. ${ }^{2}$ This final limitation reduced the working sample to 2,009. This sample permits comparisons with prior research results.

Appendix A presents an overview of all variables under study and reports their weighted means. ${ }^{3}$ The measure of total compensation used in

1. For details about the sampling techniques refer to Statistics Canada (1989).

2. A T-test was performed to determine if there was a difference between union and nonunion workers in the reporting of annual income. A T value of 2.28 was obtained and was not significant at the 1 percent level of confidence but was significant at the 5 percent.

3. The GSS used a stratified sampling design, with significant differences in fractions between strata. Hence, the survey weight must be used when producing estimates or performing analyses in order to account for this over- and under-representation. All analyses performed in this paper are weighted using the weighting variable supplied by the GSS. 
this study is an additive composite of both the respondents' reported annual income, and the average employer's cost of individual employee benefits by industry, expressed in 1989 dollars per employee per year. The GSS asked all workers to report their annual income, and to indicate if their employer provides them with a pension plan, a medical insurance plan, or a dental plan. The average employer cost of each individual employee benefit by industry, expressed in 1989 dollars, is added to the reported annual income of each worker in that industry who declared receiving a particular benefit (see Appendix B). This method of imputing benefit costs can generate a downward bias in the real union impact since all workers in the industry (union and nonunion) are imputed the same cost per benefit. Thus the union can have no impact on the value of each benefit in the industry, only on the number of benefits provided. The last step consists of transforming the resulting annual total compensation into an hourly rate by first dividing by the number of weeks worked, and then dividing by the reported total number of weekly hours worked. Using their natural logarithm, two compensation variables are under study in this paper: a) hourly wage rate (LNWAGE); and b) hourly total compensation rate (LNTCOMP).

\section{FINDINGS}

\section{Union Effect on Wage}

Equations (2) and (3) were estimated with and without incorporating selectivity variables derived from the reduced-form probit union membership equation (1). The selection-corrected results yielded an implausibly large union wage impact of 107 percent; and hence those results will not be described. ${ }^{4}$ This finding is common in the literature (Lewis 1986) and likely reflects the difficulty of identifying the union choice equation with variables that do not affect wages. Lewis (1986) has argued that this technique simply does not work, and has questioned the robustness of the results. In this light, only uncorrected union-nonunion differentials will be reported.

Table 2 provides the main results of interest, the union and nonunion determinants of wages (respectively column 1 and column 2) and of total compensation (column 3 and column 4 ). In both cases, the $\mathrm{R}^{2}$ is substantial for cross-section regressions, indicating that an important part of the variation of wages and total compensation is explained by the variables in the analysis. A union-nonunion hourly wage rate differential of 10.4 per-

4. The implausible selection results and the results of the reduced-form probit are available on request from the author. The reduced-form probit results are similar to those found in other studies that controlled for selectivity bias (e.g., Lemieux 1993 and Simpson 1985). 
TABLE 2

Wage and Total Compensation Regressions for Union and Non-Union Sectors, 1989

\begin{tabular}{|c|c|c|c|c|}
\hline \multirow[b]{3}{*}{ Variables } & \multicolumn{2}{|c|}{$\begin{array}{l}\text { Hourly Wage Rate } \\
\text { (LNWAGE) }\end{array}$} & \multicolumn{2}{|c|}{$\begin{array}{l}\text { Hourly Total Compensation Rate } \\
\text { (LNTCOMP) }\end{array}$} \\
\hline & (1) & (2) & (3) & (4) \\
\hline & Union & Non-Union & Union & Non-Union \\
\hline \multicolumn{2}{|l|}{ DIFFERENTIAL } & $10.4 \%$ & \multicolumn{2}{|c|}{$12.4 \%$} \\
\hline MALE & $0.1779 * * *$ & $0.2558 * * *$ & $0.1722^{* * *}$ & $0.2274 * * *$ \\
\hline AGE2534 & $0.2176 * * *$ & $0.1160 * * *$ & $0.1967 * * *$ & $0.1162 * * *$ \\
\hline AGE3544 & $0.2589 * * *$ & $0.1479 * * *$ & $0.2335^{* * *}$ & $0.1416^{* * *}$ \\
\hline AGE4554 & $0.2441 * * *$ & $0.1305^{* *}$ & $0.2219 * * *$ & $0.1212^{* *}$ \\
\hline AGE55 & $0.1767 * * *$ & 0.0507 & $0.1637 * * *$ & 0.0442 \\
\hline MARRIED & $0.0570 * *$ & $0.1114^{* * *}$ & $0.0542^{*}$ & $0.0941 * * *$ \\
\hline DIVORCED & -0.0704 & $0.1575^{* * *}$ & -0.0635 & $0.1347^{* *}$ \\
\hline HS & $0.0529 *$ & $0.1166^{* * *}$ & 0.0550 ** & $0.1231^{* * *}$ \\
\hline DIP & $0.1726 * * *$ & $0.1850 * * *$ & $0.1652 * * *$ & $0.1860 * * *$ \\
\hline $\mathrm{BACH}$ & $0.2129 * * *$ & $0.2667 * * *$ & $0.2080 * * *$ & $0.2609 * * *$ \\
\hline GRAD & $0.4443 * * *$ & $0.3588 * * *$ & $0.4299 * * *$ & $0.3545^{* * *}$ \\
\hline MEDSKILL & $0.0671^{* *}$ & $0.1138 * * *$ & $0.0593^{* *}$ & $0.1099 * * *$ \\
\hline HIGSKILL & $0.1045^{* * *}$ & $0.2016 * * *$ & $0.0927 * * *$ & $0.1926^{* * *}$ \\
\hline TENURE & $0.0149 * * *$ & $0.0277 * * *$ & $0.0148 * * *$ & $0.0252^{* * *}$ \\
\hline SQRDTENU & $-0.0002^{* *}$ & $-0.0004 * * *$ & $-0.0002^{* *}$ & $-0.0004 * * *$ \\
\hline IMMIG & -0.0188 & $-0.1327^{* * *}$ & -0.0184 & $-0.1195^{* * *}$ \\
\hline DISABLED & $-0.1913 * * *$ & -0.0334 & $-0.1747 * * *$ & -0.0424 \\
\hline ATLANTIC & $-0.1208 * * *$ & $-0.0789 *$ & $-0.1139 * * *$ & -0.0582 \\
\hline ONTARIO & 0.0136 & $0.0837 * * *$ & 0.0161 & $0.0902 * * *$ \\
\hline PRAIRIE & -0.0055 & -0.0219 & 0.0014 & 0.0029 \\
\hline WEST & 0.0203 & $0.0706^{*}$ & 0.0204 & $0.0790 * *$ \\
\hline FIRM99 & -0.0542 & $0.0887 * *$ & -0.0560 & $0.1081^{* * *}$ \\
\hline FIRM499 & 0.0498 & $0.1355^{* * *}$ & 0.0503 & $0.1704^{* * *}$ \\
\hline FIRM500 & 0.0780 & $0.2122^{* * *}$ & 0.0800 & $0.2386^{* * *}$ \\
\hline INCGOVER & -0.0203 & $-0.1071^{* * *}$ & -0.0192 & $-0.0931^{* * *}$ \\
\hline INCINTER & $0.0789 * * *$ & $0.0994 * * *$ & $0.0745^{* * *}$ & $0.0907 * * *$ \\
\hline INCOTHER & $0.1508 * *$ & $0.1828 * * *$ & $0.1499 * * *$ & $0.1844 * * *$ \\
\hline Constant & $1.7992 * * *$ & $1.4015^{* * *}$ & $1.8817^{* * *}$ & $1.4459 * * *$ \\
\hline $\mathrm{R}^{2}$ & $0.4885^{* * *}$ & $0.5549 * * *$ & $0.4922^{* * *}$ & $0.5646^{* * *}$ \\
\hline Observations & 844 & 1098 & 836 & 1075 \\
\hline
\end{tabular}

Note: All estimated equations included controls for Industry (10 dummy variables), and Occupation (21 dummy variables).

$* * * * * *$ : significant respectively at the $1 \%, 5 \%$ and $10 \%$ levels in a two-tailed test. 
cent is found, which is at the lower end of the 10 to 20 percent range found by aggregated studies, and the 10 to 25 percent range reported by Canadian studies using individual micro data.

The difference in magnitude between the wage differential found in this study and previous Canadian studies might be partially explained by the use of different econometric specifications. For example, when the econometric specification used by Simpson (1985) was replicated using GSS data, without correcting for possible selectivity, a union-nonunion wage differential of 18 percent was found, very close to the 19 percent differential reported by Simpson (1985). This gives some credence to our own findings and indicates that some previous studies might have failed to control for important determinants of wages. For instance, Simpson does not control for tenure, which is likely to be positively related to union status. The small magnitude of the union-nonunion wage differential may also reflect the fact that the General Social Survey was conducted in 1989, a year in which the economy was still growing. The fact that the union-nonunion wage differential varies counter-cyclically has been documented for the U.S. in Lewis (1986) and for Canada in MacDonald (1983). As well, the small differential may reflect the possibility that the differential is declining over time, given the increasing importance of competitive pressures. This is supported by the small differential of 9 percent found in one other recent study (Christofides and Swidinsky 1994) based on 1989 data.

\section{Union Effect on Total Compensation}

The total-compensation differential between the union and nonunion sectors is 12.4 percent, which is, as expected, somewhat larger than the wage differential (10.4\%) (see Table 2). Thus, the contention that the use of a measure of total compensation would yield a larger union-nonunion differential finds empirical support. The coefficient found for wage is 2 percentage points smaller than the coefficient for total compensation.

This result suggests that unions provide larger benefits for their members. Since total compensation (T) is simply the sum of wages (W) and benefits (B), the percentage impact of unions on total compensation $(\mathrm{t})$ is simply a weighted average of the percentage impact on wages (w) and the percentage impact on benefits (b), where the weights are the relative proportions of $\mathrm{W}$ and $\mathrm{B}$ in total compensation:

$\mathrm{t}=(\mathrm{W} / \mathrm{T}) \mathrm{w}+(\mathrm{B} / \mathrm{T}) \mathrm{b}$

The percentage impact of union on benefits (b) can then be inferred directly by substituting the wage impact $(\mathrm{w}=10.4)$ and the total compensation impact (12.4) in the above equation, together with the relative weights of wages and benefits. The variable means in Appendix A reveal 
that the mean hourly wage is $\$ 12.49$ (antilog of 2.525) and mean total compensation is $\$ 13.25$ (antilog of 2.584), implying that mean benefits are $\$ 0.76$, i.e., 5.7 percent of total compensation. The substitution of all these values into the above equation yields an estimate of the percentage impact of union on benefits (b) of 45.5 percent, which is very substantial. This impact is as large or larger than the 20 to 30 percent range reported in the U.S. by Freeman and Medoff (1984). Put another way, even though the union impact on total compensation is only 2 percentage points more than the impact on wages, this implies that the impact on benefits is much greater than the impact on wages, given that benefits comprise only about 6 percent of total compensation in the sample.

However, further research is required before reaching any definitive conclusions on the impact of unions on total compensation compared to wage. The data used in this study are not without limitations. For example, the average employer cost of individual employee benefits by industry, if broken down by sector (union versus nonunion) and matched with the GSS data, would have introduced a larger variance between the two sectors. This procedure would have reflected more appropriately the extent to which the union sector is more likely to receive benefits. Because all workers in each industry (union and nonunion) were imputed the same cost per benefit, unions can have no impact on the value of each benefit in the industry, only on the number of different benefits provided. This creates a downward bias in the union-nonunion total compensation differential. A direct measure of total compensation at the firm level would have been more appropriate.

\section{Control Variables}

The estimates of the control variables are generally consistent with previous empirical findings. ${ }^{5}$ Being a male as opposed to female has a significant and positive effect on the hourly wage rate, ranging from a 19.5 percent in the union sector to a substantially larger 29.1 percent in the nonunion sector. These results confirm Doiron and Riddell's (1994) findings and are consistent with the view that unions tend to reduce wage discrimination against women. The same applies for immigrants, where the negative relationship between wages and immigrant status is much stronger in the nonunion sector. The relationship between age and wages is

5. The impact of each control variable on wages and on total compensation expressed as a percentage is given as $e^{D}-1$, where $e=$ inverse natural logarithm and $D=$ the regression coefficient. This gives the percentage increase in wages or total compensation associated with a unit change in each explanatory variable. The results of the control variables discussed below are those of the wage equations because the impact of all control variables on total compensation are similar to their impact on hourly wage rate. 
also consistent with previous findings. Wages increase with age, until about age 44 , at which point they start to decline in both sectors. The relationship between age and wages is stronger in the unionized sector.

Married workers earn significantly more in both sectors compared to single workers (5.9 percent more in the unionized sector and 11.8 percent in the nonunionized sector). These results are similar to the findings of Christofides and Swidinsky (1994) and Kumar and Stengos (1986). Divorced workers earn 17.1 percent more than single workers in the nonunionized sector, but there is no significant difference between these two groups in the union sector.

Education and skill level are positively related to hourly wage rate in both sectors, but the relationships are much stronger in the nonunionized sector. These results are in line with previous findings and reinforce the belief that unions diminish the impact of market forces on wages by providing their members with a flat union premium that declines with productivity-related characteristics.

There is a significant quadratic relationship between tenure and the hourly wage rate. This result is similar to those reported by Green (1991), Swidinsky and Kupferschmidt (1991), and Robinson and Tomes (1984). Wages increase with tenure, but at a decreasing rate. Contrary to what was expected, however, this relationship is stronger in the nonunion sector. This result is peculiar considering that seniority rules are one of the cornerstones of unions. Nonetheless, it is consistent with the view that wages increase rapidly in the early years but tend to plateau in mid-career.

Workers with a disability earn 21.1 percent less than nondisabled workers in the union sector, with the relationship being small and insignificant in the nonunion sector. These results confirm those of Christofides and Swidinsky (1994) who report that nondisabled workers receive a higher salary. This relationship was expected since workers with disabilities see their relative productivity reduced and are more likely to face discrimination.

The regional wage pattern is consistent with that found in other studies, with the higher wage regions being Ontario and the Western provinces, followed by Quebec and the Prairies, and then the Atlantic provinces. Of note is the fact that the regional variation tends to be insignificant in the union sector, confirming that unions tend to standardize wages across regions. The same applies for firm size, where the positive relationship between wages and firm size is much stronger in the nonunion sector. Finally, the vector of non-labour-market sources of income is a significant predictor of the hourly wage rate. Workers who have reported receiving transfer payments from the government earn less than those 
who did not, but this relationship is significant only in the nonunionized sector. Workers who received either interest, pension, or other income earn significantly more in both sectors.

\section{Union effect for selected groups in the labour market}

The union-nonunion wage differential is a global mean for all workers in the sample. This mean can be broken down for selected groups. Differentials by gender, age, education, skill level, health status, immigrant status, industry, occupation, firm size, and geographical location are presented in the Table 3 . The differential for each group is derived from equations (2) and (3) and is given as:

$$
\mathrm{e}^{\mathrm{D}}-1
$$

where $\mathrm{e}=$ inverse natural logarithm and

$$
D=(\beta 0-\lambda 0)+(\beta 1 \bar{Z}-\gamma 1 \bar{Z})+(\beta 2 \bar{J}-\lambda 2 \bar{J})+(\beta 3 \bar{I}-\lambda 3 \bar{I})
$$

and $\bar{Z}, \bar{J}, \bar{I}$ are the full-sample means of respectively : the human capital characteristics vector, the occupational and industrial characteristics vector, and the non-labour-market sources of income vector.

Canadian female workers receive a substantially larger union-nonunion wage differential than their male counterparts. The unionized female hourly wage rate is 14.6 percent larger than the nonunionized female rate, while the unionized male hourly wage rate is only 7.8 percent larger than the nonunionized male rate. These results corroborate previous Canadian findings such as those of Christofides and Swidinsky (1994), Doiron and Riddell (1994), Lemieux (1993), Kumar and Stengos (1986), and are very close in magnitude to the findings reported by Christofides and Swidinsky (1994). The union-nonunion wage differential varies across age groups with the largest gains going to younger workers. For the first 30 years (from age 15 to 44), workers benefit from a union-nonunion wage differential of about 12 to 13 percent. Over the age of 45 , however, this differential declines to about 5 percent and remains at this level.

The union-nonunion wage differential varies across education levels, albeit the pattern is not linear. Workers with less than a high school diploma are one of the groups who gain the most from joining a union. These results are consistent with the view that the union policy of standard-rate pay increases the pay of workers earning below average wages more than workers earning above the average (Freeman and Medoff 1984). A surprisingly large wage differential of 18.6 percent is found for workers who have a post-graduate education. This result might be 
TABLE 3

Union-Nonunion Wage Differentials for Selected Categories of Workers in Canada +

\begin{tabular}{|c|c|c|}
\hline \multicolumn{3}{|l|}{ Gender } \\
\hline & Males & $7.8 \%$ \\
\hline & Females & $14.6 \%$ \\
\hline \multicolumn{3}{|l|}{ Age } \\
\hline & 15-24 Years & $11.9 \%$ \\
\hline & 25-34 Years & $13.6 \%$ \\
\hline & 35-44 Years & $12.6 \%$ \\
\hline & 45-54 Years & $4.6 \%$ \\
\hline & Over 55 Years & $4.5 \%$ \\
\hline \multicolumn{3}{|c|}{ Education } \\
\hline & Less than high school & $13.6 \%$ \\
\hline & High school diploma & $8.2 \%$ \\
\hline & Post secondary diploma & $10.7 \%$ \\
\hline & Bachelors degree & $6.2 \%$ \\
\hline & Master and/or doctorate & $18.6 \%$ \\
\hline \multicolumn{3}{|c|}{ Skill level } \\
\hline & Low skill & $19.9 \%$ \\
\hline & Medium skill & $11.4 \%$ \\
\hline & High skill & $6.4 \%$ \\
\hline \multicolumn{3}{|c|}{ Disabled } \\
\hline & Health problem & $-9.3 \%$ \\
\hline & No health problem & $11.5 \%$ \\
\hline \multicolumn{3}{|c|}{ Immigrant } \\
\hline & Immigrant & $17.1 \%$ \\
\hline & Non-immigrant & $9.1 \%$ \\
\hline \multicolumn{3}{|c|}{ Occupation } \\
\hline & White-collar & $8.9 \%$ \\
\hline & Blue-collar & $12.5 \%$ \\
\hline \multicolumn{3}{|l|}{ Industry } \\
\hline & Public administration & $3.6 \%$ \\
\hline & Non-public administration & $11.5 \%$ \\
\hline \multicolumn{3}{|c|}{ Firm size } \\
\hline & 19-less persons & $28.4 \%$ \\
\hline & 20-99 persons & $12.1 \%$ \\
\hline & 100-499 persons & $14.7 \%$ \\
\hline & 500-more persons & $3.9 \%$ \\
\hline \multicolumn{3}{|l|}{ Region } \\
\hline & Atlantic & $10.3 \%$ \\
\hline & Quebec & $14.4 \%$ \\
\hline & Ontario & $7.5 \%$ \\
\hline & Prairies & $16.6 \%$ \\
\hline & West & $8.7 \%$ \\
\hline
\end{tabular}


explained by the fact that more and more highly educated workers, professionals for example, tend to join the ranks of unions (White 1994). Lewis (1986) indicates that in the U.S. the union-nonunion wage differential is negatively related to education. The differential falls as years of schooling increase, but the magnitude of the decline per year of schooling is quite imprecise.

The wage differential declines as skill level increases, confirming that unions tend to standardize wages and hence skilled workers generally benefit less from joining unions than do less skilled workers. For example, low skilled workers and semi-skilled workers receive a union-nonunion wage differential of 19.9 percent and 11.4 percent respectively, while highly skilled workers gain only 6.4 percent. These results are similar to Lemieux (1993) and Simpson (1985), who both report a negative linear relationship between skill level and the union-nonunion wage differential.

Different union-nonunion differentials are found for workers with disabilities that limit their daily activities. Nondisabled workers gain more from unionization than those with a health problem that limits their activities. Workers with no disabilities enjoy a 11.5 percent union wage premium, while for those with a disability the differential is negative (-9.3 percent). This is a surprising result considering that unions have been traditionally instrumental in protecting workers against discrimination based on gender and race. One would have expected workers with a disability to obtain a substantially larger union-nonunion wage differential. However, union policies such as seniority can have some unintended consequences. They are suspected to be an impediment to women's efforts to obtain pay and employment equity, because female workers usually have less seniority. Similarly, they might also constitute a hurdle in accommodating the needs of disabled workers, resulting in a negative union-nonunion wage differential.

Unions increase wages for both immigrant and non-immigrant workers compared to the nonunion sector, but this increase is more substantial for immigrants. This indicates that unions are successful in protecting immigrants against discrimination and help in reducing the immigrant-nonimmigrant wage gap. Immigrant workers gain a 17.1 percent wage premium from unionization, while nonimmigrants gain only 9.1 percent. The immigrant union-nonunion wage differential is likely to be underestimated, since immigrants are more likely to work illegally in the nonunion sector, and hence to receive wages that are often below the minimum standards. If such workers were included in the data, the gap would be even wider.

Significant differences exist in union-nonunion differentials across industries and occupations. The largest gains go to workers outside public administration. Workers in public administration gain about 4 percent from 
joining a union, whereas workers outside this sector gain about 12 percent. This is consistent with the results reported by Simpson (1985) and Robinson and Tomes (1984), which both reported a larger union-nonunion wage differential in the private sector compared to the public sector. Blue-collar workers receive a larger union-nonunion wage differential than white-collar workers (12.5 percent versus 8.9 percent). No previous Canadian evidence was found for this, but these results are similar to findings reported by Hirsh and Addison (1986), Lewis (1986), and Freeman and Medoff (1984) in the U.S. labour market. These results were expected since they resemble those of skill level, since blue-collar workers are likely to be less skilled than white-collar workers. ${ }^{6}$

The wage differential declines as firm size increases, confirming that workers employed by small firms gain more from unionization than those working in large firms. Workers in firms that employ 19 or fewer persons at all locations receive a 28.4 union wage premium, while those in firms that employ 20 to 99 persons or 100 to 499 persons gain 12.1 percent and 14.7 percent respectively from unionization. Workers in larger firms (over 500 persons) benefit least from unionization, receiving a small (3.9 percent) union wage premium. These findings are consistent with U.S. findings (Lewis 1986). Gunderson and Riddell (1993) attribute this negative relationship between union-nonunion wage differential and firm size to the union threat. Because of the economies of scale in large firms, union organization becomes cheaper and leads unorganized firms to match union wages in order to avoid the unionization of their workforce.

Table 3 also shows that the wage differential varies across the five Canadian regions, ranging from a high of 16.6 percent on the Prairies to a low 7.5 percent in Ontario. Workers in the West, Atlantic and Quebec regions receive differentials of 8.7 percent, 10.3 percent and 14.4 percent. The high differential on the Prairies is not surprising considering that it is a region where agricultural and service industries are over-represented. The union-nonunion wage differential tends to be higher in rural communities and in the agricultural and service industries. In the U.S., unions have a larger impact on wages in the South and West and a smaller effect in the Northeast and the Central area (Freeman and Medoff 1984).

\section{CONCLUSION}

Our empirical results from the General Social Survey indicate a Canadian union-nonunion differential of 10.4 percent in 1989. This is at the

6. This assertion finds empirical support because $56 \%$ of all white-collar workers are codified as having high skill while there is only $41 \%$ of blue-collar workers in the same situation. 
lower end of the spectrum of Canadian studies (10 to 25 percent), suggesting that the differential may be declining as a result of greater competitive pressures in recent years. It may also reflect, however, the smaller differential that tends to prevail in periods of economic prosperity. Unionnonunion differentials were found to vary across the Canadian labour market. Higher union-nonunion differentials were associated with the following types of worker: females, younger workers, less skilled workers, low and highly educated workers, nondisabled workers, blue-collar workers, workers who are not in public administration and workers in small firms. In general, these patterns reflected the tendency for unions to standardize wages by "taking wages out of competition" and by reducing what could be discriminatory wage differentials.

As expected, the union-nonunion differential in total compensation was larger than the differential in wages, suggesting that unions have garnered larger fringe benefits for their members. This result confirms empirically that the use of a measure of wage in estimating the union-nonunion differential is misleading as it does not take into account the impact of unions on benefits, thus underestimating their impact on total compensation. The differential found for total compensation is 2 percentage points larger than the differential for wages (12.4 percent and 10.4 percent respectively). The percentage impact of unions on benefits was estimated to be around 45.5 percent. This is a very substantial impact, larger than those reported in the United States.

In closing, it is unlikely that the union-nonunion differential will increase in the foreseeable future. If anything, it will decrease as structural changes in Canada and in the global economy fundamentally alter the environment in which unions shape their bargaining goals and strategies. The global economy will make unions less capable of "taking wages out of competition" (the monopoly face). If unions want to remain an important actor in the Canadian industrial relations system and stem declining union membership, they must find ways to maintain and improve the satisfaction of their membership, since their traditional goal of raising wages and benefits might be more difficult to achieve. Unions provide an effective voice for their members; the challenge is to find ways to increase their relevance, and their membership, by increasing their importance in the operations of the workplace. 


\section{APPENDIX 1}

Variables and their Weighted Means for $1989+$

\begin{tabular}{|c|c|c|c|c|}
\hline Name & Brief Description & $\begin{array}{l}\text { Full } \\
\text { Sample }\end{array}$ & $\begin{array}{l}\text { Union } \\
\text { Sample }\end{array}$ & $\begin{array}{l}\text { Non-Union } \\
\text { Sample }\end{array}$ \\
\hline UNIONMEM & Respondent is a union member. & 0.433 & - & - \\
\hline LNWAGE & Hourly wage rate (natural logarithm). & 2.525 & 2.666 & 2.418 \\
\hline LNTCOMP & Hourly total compensation (natural logarithm). & 2.584 & 2.728 & 2.472 \\
\hline \multirow[t]{2}{*}{ MALE } & Respondent is male. & 0.603 & 0.661 & 0.559 \\
\hline & Reference age group is $15-24$ years. & 0.104 & 0.058 & 0.139 \\
\hline AGE2534 & Respondent is between $25-34$ years of age; & 0.327 & 0.291 & 0.354 \\
\hline AGE3544 & Respondent is between $35-44$ years of age; & 0.283 & 0.319 & 0.256 \\
\hline AGE4554 & Respondent is between $45-54$ years of age; & 0.182 & 0.211 & 0.160 \\
\hline AGE55 & Respondent is over 55 years of age; & 0.105 & 0.120 & 0.093 \\
\hline TENURE & Respondent's tenure with employer in years. & 10.075 & 12.278 & 8.393 \\
\hline \multirow[t]{2}{*}{ SQRDTENU } & Tenure squared. & 171.840 & 221.110 & 134.250 \\
\hline & $\begin{array}{l}\text { Reference education group is less than high } \\
\text { school. }\end{array}$ & 0.264 & 0.304 & 0.233 \\
\hline HS & Respondent has a high school diploma; & 0.302 & 0.256 & 0.338 \\
\hline DIP & Respondent has a post secondary diploma; & 0.275 & 0.289 & 0.265 \\
\hline $\mathrm{BACH}$ & Respondent has a bachelors degree; & 0.117 & 0.116 & 0.117 \\
\hline \multirow[t]{2}{*}{ GRAD } & Respondent has a masters and/or doctorate; & 0.042 & 0.035 & 0.048 \\
\hline & Reference skill group is low skill. & 0.200 & 0.213 & 0.189 \\
\hline MEDSKILL & Respondent has moderate skills; & 0.306 & 0.314 & 0.301 \\
\hline HIGSKILL & Respondent has high skills; & 0.494 & 0.473 & 0.510 \\
\hline DISABLED & $\begin{array}{l}\text { Respondent has a health problem which restrains } \\
\text { activities. }\end{array}$ & 0.042 & 0.044 & 0.041 \\
\hline \multirow{2}{*}{ IMMIG } & Respondent place of birth is not Canada. & 0.173 & 0.147 & 0.193 \\
\hline & $\begin{array}{l}\text { Reference category is single (never been } \\
\text { married). }\end{array}$ & 0.209 & 0.170 & 0.231 \\
\hline MARRIED & Respondent is married, living in common-law; & 0.720 & 0.747 & 0.700 \\
\hline DIVORCED & $\begin{array}{l}\text { Respondent is divorced, separated, widow/ } \\
\text { widower; }\end{array}$ & 0.071 & 0.084 & 0.069 \\
\hline \multirow[t]{2}{*}{ Lambda $(\lambda)$} & Selectivity correction variable. & 0.533 & 0.616 & 0.470 \\
\hline & Reference region is Quebec. & 0.299 & 0.342 & 0.267 \\
\hline ATLANTIC & Respondent is living in an Atlantic province; & 0.072 & 0.063 & 0.079 \\
\hline ONTARIO & Respondent is living in Ontario; & 0.381 & 0.349 & 0.406 \\
\hline PRAIRIE & Respondent is living in a Prairie province; & 0.065 & 0.072 & 0.059 \\
\hline \multirow[t]{2}{*}{ WEST } & $\begin{array}{l}\text { Respondent is living in Alberta or British } \\
\text { Colombia; }\end{array}$ & 0.183 & 0.175 & 0.188 \\
\hline & Reference group is 19 or less at all locations. & 0.144 & 0.035 & 0.228 \\
\hline FIRM99 & 20 to 99 persons employed at all locations; & 0.169 & 0.130 & 0.199 \\
\hline FIRM499 & 100 to 499 persons employed at all locations; & 0.187 & 0.189 & 0.186 \\
\hline FIRM500 & 500 or more persons employed at all locations; & 0.499 & 0.646 & 0.388 \\
\hline INCGOVER & $\begin{array}{l}\text { Respondent has received income from } \\
\text { government. }\end{array}$ & 0.299 & 0.299 & 0.299 \\
\hline INCINTER & $\begin{array}{l}\text { Respondent has received income from interest, } \\
\text { pension. }\end{array}$ & 0.304 & 0.326 & 0.287 \\
\hline INCOTHER & Respondent has received other type of income. & 0.034 & 0.029 & 0.038 \\
\hline
\end{tabular}

+ All estimated equations also included controls for Industry (10 dummy variables), and Occupation (21 dummy variables). 
APPENDIX 2

The Cost of Individual Employee Benefits by Industry,

Expressed in Dollars per Employee per Year (1989)

\begin{tabular}{lccc}
\hline Industry & Pension plan & $\begin{array}{c}\text { Medical insurance } \\
\text { plan }\end{array}$ & Dental plan \\
\hline Manufacturing & 1,192 & 283 & 320 \\
Mining & 1,218 & 178 & 358 \\
Construction & 1,334 & 141 & 419 \\
Utilities & 2,251 & 297 & 427 \\
Transportation & 2,134 & 257 & 357 \\
Trade & 857 & 190 & 279 \\
Finance, insurance & 1,186 & 266 & 284 \\
Hospitals & 477 & 199 & 115 \\
Education & 1,606 & 78 & 233 \\
Government & 1,912 & 211 & 340 \\
Other & 1,161 & 218 & 325 \\
\hline
\end{tabular}

Source: Peat Marwick Stevenson \& Kellogg. 1989. Employee Benefit Costs in Canada. Management Consultants, Toronto.

\section{BIBLIOGRAPHY}

CHRISTOFIDES, L. N., and R. SWIDINSKY. 1994. "Wage Determination by Gender and Visible Minority Status: Evidence from the 1989 LMAS." Canadian Public Policy, Vol. 20, 34-51.

DOIRON, D. J., and W. C. RIDDELL. 1994. "The Impact of Unionization on Male-Female Earnings Differentials in Canada." Journal of Human Ressources, Vol. 29, 504-534.

FREEMAN, R. B., and J. L. MEDOFF. 1984. What Do Unions Do? New York: Basic Books.

GRANT, E. K., R. SWIDINSKY, and J. VANDERKAMP. 1987. "Canadian UnionNonunion Wage Differentials." Industrial and Labor Relations Review, Vol. 41, 93-107.

GREEN, D. A. 1991. A Comparison of Estimation Approaches for the UnionNonunion Wage Differential. UBC Department of Economics. Working Paper 91-13.

GUNDERSON, M., and W. C. RIDDELL. 1993. Labour Market Economics. 3rd ed. Toronto: McGraw-Hill Ryerson.

HIRSH, B. T., and J. T. ADDISON. 1986. The Economic Analysis of Unions: New Approaches and Evidence. Boston: Allen and Unwin.

KUmAR, P. 1972. "Differentials in Wage Rates of Unskilled Labor in Canadian Manufacturing Industries." Industrial and Labor Relations Review, Vol. 26, 631-645. 
KUMAR, P., and T. STENGOS. 1985. "Measuring the Union Relative Wage Impact: A Methodological Note." Canadian Journal of Economics, Vol. $18,182-189$.

KUMAR, P., and T. STENGOS. 1986. "Interpreting the Wage Gap Estimate from Selectivity Correction Techniques Using Micro-Data." Economics Letters, Vol. 20, 191-195.

LEE, L. F. 1978. "Unionism and Wage Rates: A Simultaneous Equations Model with Qualitative and Limited Dependant Variables." International Economic Review, Vol. 19, 415-433.

LEMIEUX, T. 1993. "Unions and Wage Inequality in Canada and in the United States." Small Differences that Matter. D. Card and R. B. Freeman, eds. Chicago: University of Chicago Press, 69-107.

LEWIS, H. G. 1986. Union Relative Wage Effects: A Survey. Chicago: The University of Chicago Press.

MACDONALD, G. M. 1983. "The Size and Structure of Union-Non-Union Wage Differential in Canadian Industry: Corroboration, Refinement, and Extension." Canadian Journal of Economics, Vol. 16, 480-485.

MACDONALD, G. M., and J. C. EvANS. 1981. "The Size and Structure of Union-Non-Union Wage Differentials in Canadian Industry." Canadian Journal of Economics, Vol. 14, 216-231.

MADDALA, G. S. 1983. Limited-Dependent and Qualitative Variables in Econometrics. New York: Cambridge University Press.

PEAT Marwick STEVEnSON \& KellogG. 1989. Employee Benefit Costs in Canada. Management Consultants, Toronto.

RENAUD, S. 1997. "Union and Wages in Canada: A Review of the Literature." Proceedings of the 33rd Annual Conference of the Canadian Industrial Relations Association. St. Catharines: CIRA, 211-225.

ROBINSON, C., and N. TOMES. 1984. "Union Wage Differentials in the Public and Private Sectors: A Simultaneous Equation Specification." Journal of Labor Economics, Vol. 2, 106-127.

SIMPSON, W. 1985. "The Impact of Unions on the Structure of Canadian Wages: An Empirical Analysis with Micro data." Canadian Journal of Economics, Vol. 18, 164-181.

STATISTICS CANADA. 1989. General Social Survey: Education and Work 1989. Ottawa.

SWIDINSKY, R., and M. KUPFERSCHMIDT. 1991. "Longitudinal Estimates of the Union Effects on Wages, Wage Dispersion and Pension Fringe Benefits." Industrial Relations, Vol. 46, 819-838.

WHITE, G. F. 1994. "The Union/Non-Union Earnings Differential for Professionals." Proceedings of the 30th Annual Conference of the Canadian Industrial Relations Association. E. Déom and A. E. Smith, ed. Quebec: CIRA, 269-279. 


\section{RÉSUMÉ}

Syndicats, salaires et rémunération globale au Canada : une analyse empirique

Il est bien connu que les syndicats ont un impact sur la rémunération des travailleurs. Les études canadiennes sur le sujet démontrent unanimement qu'ils augmentent le salaire de leurs membres comparativement aux travailleurs qui ne sont pas syndiqués. Les études utilisant des données micro-économiques rapportent un différentiel salarial d'environ 10 à 25 pour cent alors que celles qui ont utilisé des données agrégées rapportent un écart salarial d'environ 10 à 20 pour cent. Il existe un vide empirique dans la littérature canadienne quant à l'effet des syndicats sur les avantages sociaux et sur la rémunération globale. L'hypothèse principale de la présente recherche est à l'effet que le différentiel salarial que les syndicats procurent à leurs membres est sous-estimé lorsque l'on utilise une mesure de salaire.

Cet article examine non seulement l'impact des syndicats sur les salaires mais également leur effet sur les avantages sociaux de même que sur la rémunération globale des travailleurs au Canada. Il s'agit de la première étude canadienne à fournir des évidences empiriques sur ce sujet. De plus, elle procure également une estimation récente du différentiel salarial syndical, de même que les écarts salariaux pour une série de sous-groupes du marché du travail.

Pour réaliser notre étude, nous avons utilisé des données micro-économiques de 1989 tirées de l'Enquête sociale générale de Statistique Canada. Nos analyses statistiques ont été réalisées auprès d'un souséchantillon de 2009 salariés au sens du Code du travail. Nous avons suivi la procédure empirique d'Heckman-Lee avec et sans la correction de sélectivité pour l'adhésion syndicale. Il est à noter que la procédure de correction de sélectivité a produit des estimations irréalistes des différentiels de rémunération.

Nos résultats démontrent que les travailleurs syndiqués jouissent toujours d'un différentiel salarial appréciable de 10,4 pour cent. Cet écart indique que le différentiel salarial syndical pourrait s'être atténué au cours des dernières années. Nous avons trouvé que le différentiel de rémunération globale est de 12,4 pour cent, soit 2 points de pourcentage de plus que le différentiel obtenu avec la mesure de salaire. Nous avons estimé que l'impact des syndicats sur les avantages sociaux est de 45,5 pour cent, ce qui est supérieur à ce qui a été trouvé par différentes études américaines (entre 20 et 30 pour cent). Enfin, nos résultats indiquent que les syndicats procurent un différentiel salarial positif aux femmes, aux jeu- 
nes travailleurs, aux travailleurs sous-qualifiés, aux travailleurs peu et très scolarisés, aux travailleurs qui n'ont pas de handicaps, aux cols bleus, aux travailleurs qui ne sont pas dans l'administration publique et à ceux qui œuvrent dans les petites entreprises.

\section{RESÚMEN}

Sindicatos, salarios y compensación total en Canadá : Un estudio empírico

Este estudio presenta las primeras evidencias empíricas del efecto de los sindicatos en la remuneración y la compensación en general en Canadá. También establece nueva evidencia acerca del impacto de los sindicatos en los escalafones de salario de diferentes grupos en el mercado laboral. Utilizado información del Estudio Social General Canadiense de 1989, los resultados demuestran una aumentación de la compensación de $12.4 \%$ y de $10.4 \%$ de los salarios en reacción a la implicación de los sindicatos. Aun y cuando el impacto de los sindicatos en la compensación en general es $2 \%$ mas grande que en los salarios, y dado que los beneficios marginales no representan que el $6 \%$ del total de la compensación en este caso, el porcentaje de impacto de los sindicatos en el movimiento de los salarios es estimado en $45.5 \%$. Esta ultima estimación asigna una influencia radical de los sindicatos en el movimiento de los salarios, influencia que es mas grande que aquella encontrada en los Estados Unidos. 